Background and aims SLE patient who had deficiency of vitamin D, had worsen clinical manifestation. Vitamin D and Curcumin ; a novel Vitamin D Receptor (VDR) ligand, are immunomodulator. The purpose of this study, to compare efficacy whether curcumin supplementation in vitamin D treatment will give improvement of disease activity, fatigue and proteinuria in SLE patient with vitamin D deficiency.

Methods This study was a double blind RCT included 40 active SLE patient more than 18 yo with level 25(OH)D3 $\leq 30 \mathrm{ng} / \mathrm{ml}$ were enrolled for this study. There were divided into 2 group, control group who received cholecalciferol $3 \times$ 400 IU plus placebo and trial group who received cholecalciferol $3 \times 400 \mathrm{IU}$ and curcumin $3 \times 20 \mathrm{mg}$ for 6 months. Demorgrafic data, family history, medications, laboratory test, SLEDAI and FSS were taken before and after treatment. Serum cytokines were measure uisng ELISA. The results between 2 groups were evaluated with independent t-test and spearman/pearson correlation test using SPSS software.

Results Age of participant are 28.1 \pm 8.1 , disease duration 3.1 \pm 2.3 year. The addition of curcumin in the suplemtation treatment with vitamin D increase the benefit of vitamin D. Combination of curcumin and vitamin $\mathrm{D}$ result in better disease activity suppression, less fatigue and less proteinuria compare with vitamin D supplementation alone. The clinical improvement were related to decrease in proinflammatory cytokines ( IFNg, TNFa and IL-17 ). There were no major adverse events in both groups.

Conclusions The addition of curcumin to the vitamin D supplementation therapy result in better efficacy.

\section{IMMUNE MODULATION EFFECTS OF CURCUMIN IN PRISTANE INDUCED LUPUS MICE}

${ }^{1} \mathrm{H}$ Susiianti*, ${ }^{2} \mathrm{CS}$ Wahono, ${ }^{3} \mathrm{M}$ Zaka Pratama, ${ }^{1} \mathrm{U}$ Kalsum, ${ }^{1} \mathrm{~N}$ Nurdiana, ${ }^{2} \mathrm{H}$ Kalim. ${ }^{1}$ Brawijaya University, Clinical Pathology, Malang, Indonesia; ${ }^{2}$ Brawijaya University, Rheumato-Immunology, Malang, Indonesia; ${ }^{3}$ Brawijaya University, Internal Medicine, Malang, Indonesia

\subsection{6/lupus-2017-000215.93}

Background and aims The aim of this study is to assess the effect of curcumin treatment on the clinical manifestations, Th-cells subsets/Treg percentages, pro-inflammatory cytokines and autoantibody production of pristane induced lupus mice.

Methods Forty female Balb/c mice ( 6-8 weeks of age with body weight 30-50 gram ) were single injected with pristane intraperitoneally for lupus induction. The mice were assigned to 3 groups treated with 3 different doses of curcumin given $12.5 \mathrm{mg} /, 50 \mathrm{mg} /$, and $200 \mathrm{mg} / \mathrm{kgBW} /$ day. One group of mice as control was not tretaed with curcumin. The mice were monitored for clinical manifestations ( arthritis score, proteinuria, and body weight). After 32 weeks post injection, the spleens were taken and assayed for Th1, Th2, Th17, and Treg percentages using flow cytometry. Serum was collected for ANA, IL- 6 , and IFN- $\alpha$ measurement by ELISA.

Results Arthritis score was lower in all groups treated with curcumin $(p=0.000)$. However, proteinuria and body weights were not statistically different between all groups of mice.
ANA levels decreased significantly after treatment with $200 \mathrm{mg} / \mathrm{kgBW} /$ day of curcumin $(\mathrm{p}=0.024)$. The decreased of Th1, Th2, and Th17 percentages were also seen after treatment of $200 \mathrm{mg} / \mathrm{kgBW} /$ day of curcumin $(\mathrm{p}=0.043, \mathrm{p}=0.026$, and $\mathrm{p}=0.009$ ); however, only slight increase of Treg percentages was seen. Treatment with $200 \mathrm{mg} / \mathrm{kgBW} /$ day of curcumin decreased serum IL-6 and IFN- $\alpha$ levels $(p=0.012$ and $\mathrm{p}=0.003)$.

Conclusions Curcumin protects manifestation of arthritis in pristane induced lupus mice and ANA production, modulating Th-cell subsets, and inhibiting production of proinflammatory cytokines

\section{DEVELOPMENT OF THERAPY USING BRYOPHYLLUM PINNATUM TO DECREASE MATURATION AND INCREASE APOPTOTIC B CELLS FROM BALB/C LUPUS MICE: IN SILICO AND IN VITRO STUDY APPROACH}

${ }^{1} \mathrm{~K}$ Handono*, ${ }^{2}$ TWI Dantara, ${ }^{3}$ E.S. Dewi, ${ }^{4} \mathrm{MZ}$ Pratama, ${ }^{5} \mathrm{~N}$ Nurdiana. ${ }^{1}$ Faculty of Medicine Brawijaya University, Clinical Pathology, Malang, Indonesia; ${ }^{2}$ Faculty of Medicine Brawijaya University, Biomedical Science, Malang, Indonesia; ${ }^{3}$ Faculty of Medicine Brawijaya University, Medical Surgeon Nursing, Malang, Indonesia; ${ }^{4}$ Faculty of Medicine Brawijaya University, Internal Medicine, Malang, Indonesia; ${ }^{5}$ Faculty of Medicine Brawijaya University, Clinical Pharmacology, Malang, Indonesia

\subsection{6/lupus-2017-000215.94}

Background and aims To investigate the effect of Bryophyllum pinnatum extract to $\mathrm{B}$ cells by supressing maturation and increasing apoptosis of B cells.

Methods In silico study was done to understand affinity of Bryophillin A, Bryophillin B, Bryotoxin A, Bryotoxin B, Kaempferol, p-coumaric acid aiffinity in Bryophyllum pinnatum against $\mathrm{B}$ cell activating factor (BAFF) and its receptors: $\mathrm{B}$ cell activating factor receptors (BAFF-R), transmembrane activator and calcium modulator and cyclophilin ligand interactor (TACI), and B-cell maturation antigen (BCMA). In vitro study was done by culturing $\mathrm{B}$ cells from pristane induced lupus BALB/c mice's spleen. B cells were cultured into four groups, one as a control and the other groups given Bryophyllum pinnatum extract $(0.02,0.1$, and $0.5 \mathrm{ug} / \mathrm{L})$. Precentage of maturation $\left(\mathrm{CD} 19^{+} / \mathrm{CD} 38^{+}\right)$and apoptosis (Annexin $\mathrm{V}^{+} / \mathrm{PI}^{+}$) of $\mathrm{B}$ cells determined using flow cytometry. Immunocytochemistry assay was performed to determine the expression of transcription factor NF-kB p65.

Results Molecular docking results show that all of Bryophyllum pinnatum compounds studied have affinities for BAFF-R, TACI, BCMA and BAFF. Flow cytometry assay showed significantly decrease in percentages of maturation of $\mathrm{B}$ cells in all doses $(p<0.05)$, significantly increase in percentages of apoptotic B cells in dose $0.5 \mathrm{ug} / \mathrm{L}(\mathrm{p}<0.05)$. The results of immunocytochemistry showed decreased expression of NF-kB p65 were significant at all doses $(\mathrm{p}<0.05)$.

Conclusions In silico and in vitro study revealed that Bryophyllum pinnatum is potential natural product which may be used for B cell depleting agent in development of biosimilar therapy in systemic lupus erythematosus. 